\title{
The Epidemic Of The Metabolic Syndrome Among The Palestinians In The Gaza Strip
}

This article was published in the following Dove Press journal:

Diabetes, Metabolic Syndrome and Obesity: Targets and Therapy

\author{
Amal Shahwan Jamee $e^{1-3}$ \\ Victor Aboyans (D) ${ }^{1,2,4}$ \\ Julien Magne ${ }^{1,2,4}$ \\ Pierre Marie Preux ${ }^{1,2}$ \\ Philippe Lacroix ${ }^{1,2,5}$
}

\begin{abstract}
'Tropical Neuroepidemiology, Inserm UMR 1094, Limoges, France; ${ }^{2}$ School of Medicine, Institute of Neuroepidemiology and Tropical Neurology, CNRS FR 3503 GEIST, University of Limoges, Limoges, France; ${ }^{3}$ Department of Cardiology, Ministry of Health, Palestine,

${ }^{4}$ Department of Cardiology, Dupuytren University Hospital, Limoges, France;

${ }^{5}$ Department of Thoracic and Vascular Surgery - Vascular Medicine, Dupuytren University Hospital, Limoges, France
\end{abstract}

Background: The metabolic syndrome (MetS) is a major public health and clinical challenge worldwide. However, limited data are available in the Gaza strip. This study was undertaken to evaluate the prevalence of MetS and its association with atherosclerotic risk factors and cardiovascular diseases among Gazan adults' community.

Methods: A cross-sectional study was conducted in 2017, among all adults $\geq 25$ years of age. Participants were selected by stratified cluster sampling method, in five governorates (urban, camps and rural) of Gaza strip. Questionnaires on socioeconomic status, lifestyle and cardiovascular risk factors were completed for 2107 participants. The cardiovascular diseases included clinical history of coronary artery disease (CAD), Lower extremity artery disease (LEAD diagnosed as ankle brachial index < 0.90) and history of stroke. MetS was defined based on the International Diabetes Federation criteria (IDF).

Results: Among participants, 864 (41\%) fulfilled the definition of MetS higher in females than males (50\% vs 39\%). In both genders, MetS prevalence increased significantly with age $(\mathrm{p}<0.001)$. Subjects with MetS were more obese (73.0\% vs $29.4 \%)$, hypertensive $(49.9 \%$ vs $13.0 \%$ ), diabetic (36.8\% vs $5.8 \%$ ) and had more often low physical activity (58.1\% vs $41.3 \%)$. Additionally, lipids profiles disorders were more prevalent in cases with MetS. We found MetS significantly associated with all cardiovascular conditions with odd-ratio $(95 \% \mathrm{CI})$ respectively at $2.4(95 \% \mathrm{CI} 1.8-3.4)$ for CAD, 1.5 (95\% CI1.1-1.9) for LEAD and 2.1 (95\% CI 1.3-3.5) for stroke.

Conclusion: The MetS is highly prevalent in the Palestinian population, particularly among women. Subjects with MetS are at significantly elevated risk for cardiovascular diseases.

Keywords: metabolic syndrome, risk factors, cardiovascular disease, Palestine

\section{Introduction}

The Metabolic syndrome (MetS) is a major public health and clinical challenge worldwide. It is defined as a cluster of clinical and metabolic disorders associated with increased risk of atherosclerosis cardiovascular disease (CVD) and mortality. ${ }^{1}$ The overall prevalence of MetS varies according to geographic and socio-demographic factors, as well as the diagnostic criteria. Globally, the prevalence of MetS ranges from $10 \%$ to $40 \% .^{2}$ The MetS increases by 5 -fold the risk of type 2 diabetes mellitus and 2-fold the risk of developing CVD. ${ }^{3}$ Also, patients with MetS are 2-4 times more likely to die of cardiovascular events than those without MetS. ${ }^{4}$ The MetS occurs more frequently through the combination of several factors and increase the cardiovascular risk beyond the risk associated with individual factors alone. $^{5}$ The risk increases with the number of MetS components present. ${ }^{6}$ The syndrome occurs most often in populations characterized by high prevalence of
Correspondence: Amal Shahwan Jamee School of Medicine, Institute of Neuroepidemiology and Tropical Neurology, University of Limoges, 2 rue du Dr Marcland, Limoges 87025, France Tel +337541391 I2

Email dr_amal08@yahoo.fr 
obesity and physical inactivity. ${ }^{3}$ The major causes leading to MetS are insulin resistance, obesity, unhealthy lifestyle, and genetic predisposition. ${ }^{7,8}$ In the Middle-East region, the MetS affects one in four people. ${ }^{9}$ In Palestine, some studies on MetS based on inhomogeneous criteria are available. The prevalence of MetS varies from $17.1 \%$ to 23\%; however, none study reported the relationship between cardiovascular risk factors or CVD and MetS. ${ }^{10,11}$

This study aims to determine a recent prevalence of MetS as defined by IDF criteria, and to examine the associated atherosclerotic risk factors and cardiovascular diseases among large Gazan community.

\section{Methods}

\section{Subjects And Study Design}

We conducted a cross-sectional study using stratified cluster sampling method in 2017 in the five-residential governorates of Gaza. In each governorate, one city was selected; within each city one camp area and 2-3 rural and urban areas were randomly chosen. Within each camp, either urban, or rural, a sample block (a group of buildings that form a locality) was selected and a cluster of 15 to 20 households were randomly chosen. The investigators went from door to door, and in every house, all subjects ageing $\geq 25$ years were interviewed and examined. In this study, 2240 individuals were included. Among them, 133 subjects were excluded from the analysis due to either an $\mathrm{ABI}$ $>1.40$ (114) or missing data on waist circumferential (WC), and biochemical values included in the definition of the MetS (19), leaving 2107 subjects for the analysis.

\section{Data Collection}

Each participant was interviewed and completed a questionnaire that included: socio-demographic variables, lifestyle, medical history of chronic diseases, and the international physical activity questionnaire (IPAQ) short form.

\section{Measurements}

All measurements were taken by nurse's staff. Height and weight were measured with the foot and wearing light clothing, with a wall-mounted stadiometer and an electronic scale (Seca, Hamburg, Germany). Body mass index (BMI kg/m²) was calculated as the weight in kilograms divided by the square of the height in meters. Waist circumference was measured at the mid-distance between the tenth rib and the iliac crest. Blood pressure (BP) was measured once in both arms. A hand-held Doppler probe was used to measure the blood pressure in both arms and ankles (both posterior tibial and dorsalis pedis arteries). ${ }^{12}$ The ankle brachial index (ABI) was measured at each leg and the lowest between the two ankles was retained as the subject's ABI.

Venous blood sample for lipids profiles including total cholesterol (TC) high-density lipoprotein cholesterol (HDL-C) and triglycerides were taken by nurse's staff from antecubital vein and sent to the laboratory for analysis using standard methods.

The low-density lipoprotein cholesterol (LDL-C) was calculated by Friedewald equation. Whole blood glucose was measured using glucometer. The study was conducted in accordance with the declaration of Helsinki and the Palestinian research institution.

\section{Definition Of Metabolic Syndrome}

According to the International Diabetes Federation (IDF) definition, MetS was defined in case of $\mathrm{WC} \geq 94 \mathrm{~cm}$ in men and $\geq 80 \mathrm{~cm}$ in women (all participants were Caucasians and the European norms are used for Eastern Mediterranean population), plus two of the four following factors: 1) high blood pressure $\geq 130 / 85 \mathrm{mmHg}$ or on anti-hypertensive drugs, 2) triglycerides level $\geq 150 \mathrm{mg} / \mathrm{dL}$, 3) low HDL cholesterol level $<40 \mathrm{mg} / \mathrm{dL}$ in males and $<50 \mathrm{mg} / \mathrm{dL}$ in females, and 4) fasting glucose level $\geq 100 \mathrm{mg} / \mathrm{dL}$ or known to have type-2 diabetes. ${ }^{13}$

Diabetes mellitus (DM) was defined as capillary blood sugar level $\geq 126 \mathrm{mg} / \mathrm{dL}$ if the participant was fasting or $\geq 200$ $\mathrm{mg} / \mathrm{dL}$ if the participant was non-fasting and or self-reported as currently taking any diabetes medications. ${ }^{14}$ We considered subjects with hypertension (HTN), if their average systolic blood pressure (SBP) in both arms was $\geq 140 \mathrm{mmHg}$ or their average diastolic blood pressure (DBP) $\geq 90 \mathrm{mmHg}$, or if they were being treated for HTN. ${ }^{15,16}$ Coronary artery disease (CAD) was defined in our study by self-reported history of hospitalization for angina pectoris, myocardial infarction, procedures performing percutaneous coronary intervention or coronary bypass graft and after verification of their medical prescription list. Stroke history was identified in case of positive answer to the question: "Have you ever been told by a physician that you suffered a stroke? And by a documented history of stroke. Lower extremity artery disease (LEAD) was defined as ABI $<0.90$.

\section{Statistical Analysis}

All data were analyzed with the SPSS statistical software version 22.0 (Chicago, Illinois, USA). Continuous variables were expressed as mean \pm standard deviation, and 
categorical variables were expressed as percentages. The and without MetS was expressed by frequency distribution comparison of qualitative variables between persons with and cross-tabulation and was compared using the

Table I The Characteristics Of The Study Participants With And Without Metabolic Syndrome

\begin{tabular}{|c|c|c|c|c|}
\hline Variables & $\begin{array}{l}\text { Whole Population } \\
n=2107\end{array}$ & $\begin{array}{l}\text { MetS } \\
n=864(41 \%)\end{array}$ & $\begin{array}{l}\text { No MetS } \\
n=1243 \text { (59\%) }\end{array}$ & P-value \\
\hline $\begin{array}{l}\text { Age, years } \\
\text { Women, n (\%) }\end{array}$ & $\begin{array}{l}47.17 \pm 14.3 \\
1067(50.6)\end{array}$ & $\begin{array}{l}53.2 \pm 12.7 \\
532(49.9)\end{array}$ & $\begin{array}{l}42.9 \pm 13.9 \\
535(50.1)\end{array}$ & $\begin{array}{l}<0.001 \\
<0.001\end{array}$ \\
\hline $\begin{array}{l}\text { Areas } \\
\text { Urban, n (\%) } \\
\text { Rural, n (\%) } \\
\text { Camp, n (\%) }\end{array}$ & $\begin{array}{l}752(35.6) \\
493(23.4) \\
863(41.0)\end{array}$ & $\begin{array}{l}318(36.8) \\
196(22.7) \\
350(40.5)\end{array}$ & $\begin{array}{l}433(34.8) \\
297(23.9) \\
513(41.3)\end{array}$ & 0.623 \\
\hline $\begin{array}{l}\text { Education level* } \\
\text { Primary education, n (\%) } \\
\text { Secondary + High school, n (\%) } \\
\text { University + Post graduate, n (\%) }\end{array}$ & $\begin{array}{l}324(15.4) \\
1082(51.4) \\
701(33.3)\end{array}$ & $\begin{array}{l}180(20.8) \\
461(53.4) \\
223(25.8)\end{array}$ & $\begin{array}{l}144(11.6) \\
621(50.0) \\
478(38.5)\end{array}$ & $<0.001$ \\
\hline $\begin{array}{l}\text { Physical activity } \\
\text { Low, n (\%), n (\%) } \\
\text { Moderate, n (\%) } \\
\text { High, n (\%) }\end{array}$ & $\begin{array}{l}1015(48.2) \\
657(31.2) \\
435(20.6)\end{array}$ & $\begin{array}{l}502(58.1) \\
233(27.0) \\
129(14.9)\end{array}$ & $\begin{array}{l}513(41.3) \\
424(34.1) \\
306(24.6)\end{array}$ & $<0.001$ \\
\hline $\begin{array}{l}\text { Income } \\
<300 \$ \text {, n (\%) } \\
\geq 300 \$ \text {, n (\%) }\end{array}$ & $\begin{array}{l}\mid 326(62.9) \\
78 \mid(37 \mid)\end{array}$ & $\begin{array}{l}574(66.4) \\
290(33.6)\end{array}$ & $\begin{array}{l}752(60.5) \\
491(39.5)\end{array}$ & 0.006 \\
\hline $\begin{array}{l}\text { Marital status* } \\
\text { Single, n (\%) } \\
\text { Married } \\
\text { Divorced or widow, n (\%) }\end{array}$ & $\begin{array}{l}161(7.6) \\
1792(85) \\
154(7.3)\end{array}$ & $\begin{array}{l}28(3.2) \\
740(85.6) \\
96(I I .1)\end{array}$ & $\begin{array}{l}\text { I } 33(10.7) \\
1052(84.6) \\
58(4.7)\end{array}$ & $<0.001$ \\
\hline $\begin{array}{l}\text { Body mass index } \\
\text { Normal }\left(18.5-25.9 \mathrm{~kg} / \mathrm{m}^{2}\right), \mathrm{n}(\%) \\
\text { Overweight }\left(25.9-29.9 \mathrm{~kg} / \mathrm{m}^{2}\right), \mathrm{n}(\%) \\
\text { Obese } \geq\left(30 \mathrm{~kg} / \mathrm{m}^{2}\right), \mathrm{n}(\%)\end{array}$ & $\begin{array}{l}419(19.9) \\
691(32.8) \\
997(47.3)\end{array}$ & $\begin{array}{l}18(2.1) \\
215(24.9) \\
631(73.0)\end{array}$ & $\begin{array}{l}40 I(32.2) \\
476(38.3) \\
366(29.4)\end{array}$ & $<0.001$ \\
\hline $\begin{array}{l}\text { CVD risk factors } \\
\text { Hypertension, n (\%) } \\
\text { Diabetes mellitus, n (\%) } \\
\text { Current smoking, n (\%) }\end{array}$ & $\begin{array}{l}592(28.1) \\
390(18.5) \\
489(23.2)\end{array}$ & $\begin{array}{l}431(49.9) \\
318(36.8) \\
138(16)\end{array}$ & $\begin{array}{l}161(13.0) \\
72(5.8) \\
351(28.2)\end{array}$ & $\begin{array}{l}<0.001 \\
<0.001 \\
<0.001\end{array}$ \\
\hline $\begin{array}{l}\text { Lipids profiles } \\
\text { Total Cholesterol } \geq 240 \text { (mg/dL), n (\%) } \\
\text { Low HDL cholesterol, n (\%) } \\
\text { LDL cholesterol level } \geq 160, \mathrm{n}(\%) \\
\text { Triglycerides level } \geq 150, \mathrm{n}(\%)\end{array}$ & $\begin{array}{l}178(8.4) \\
178(8.4) \\
1474(70.0) \\
833(39.5)\end{array}$ & $\begin{array}{l}100(11.6) \\
748(88.6) \\
90(10.5) \\
591(68.4)\end{array}$ & $\begin{array}{l}78(6.3) \\
726(58.4) \\
77(6.2) \\
242(19.5)\end{array}$ & $\begin{array}{l}<0.001 \\
<0.001 \\
<0.001 \\
<0.001\end{array}$ \\
\hline $\begin{array}{l}\text { CVD comorbidities } \\
\text { CAD, } n(\%) \\
\text { Stroke, } n(\%) \\
\text { LEAD }(A B \mid<0.90), n(\%)\end{array}$ & $\begin{array}{l}170(8.1) \\
63(3.0) \\
274(13.0)\end{array}$ & $\begin{array}{l}104(12.0) \\
37(4.3) \\
134(15.5)\end{array}$ & $\begin{array}{l}66(5.3) \\
26(2.1) \\
140(11.3)\end{array}$ & $\begin{array}{l}<0.001 \\
0.004 \\
0.004\end{array}$ \\
\hline $\begin{array}{l}\text { Medications use } \\
\text { Statins, n (\%) } \\
\text { Aspirin, n (\%) }\end{array}$ & $\begin{array}{l}226(10.7) \\
498(23.6)\end{array}$ & $\begin{array}{l}176(20.4) \\
318(36.8)\end{array}$ & $\begin{array}{l}50(4.0) \\
180(14.5)\end{array}$ & $\begin{array}{l}<0.001 \\
<0.001\end{array}$ \\
\hline
\end{tabular}

Notes: Education status*: primary level (0-6 years), secondary level (7-12), and high level >12 years. Marital status*: single. married and divorced or widow. 


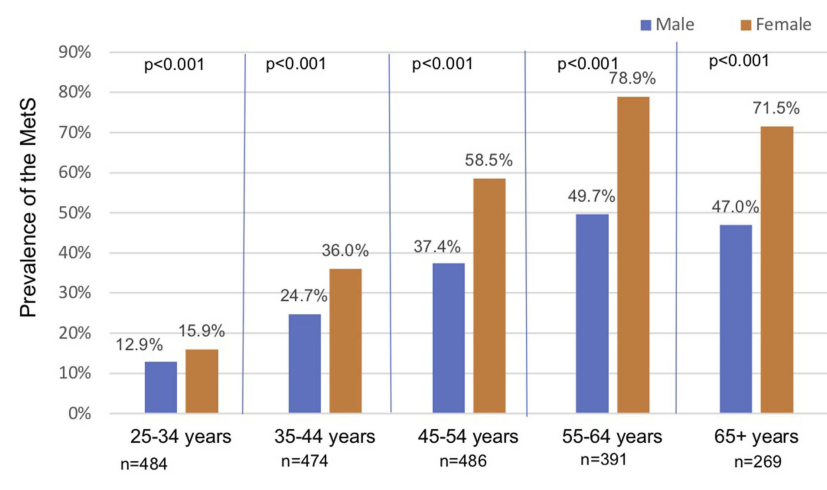

Figure I Metabolic syndrome according to gender and stratified by age group.

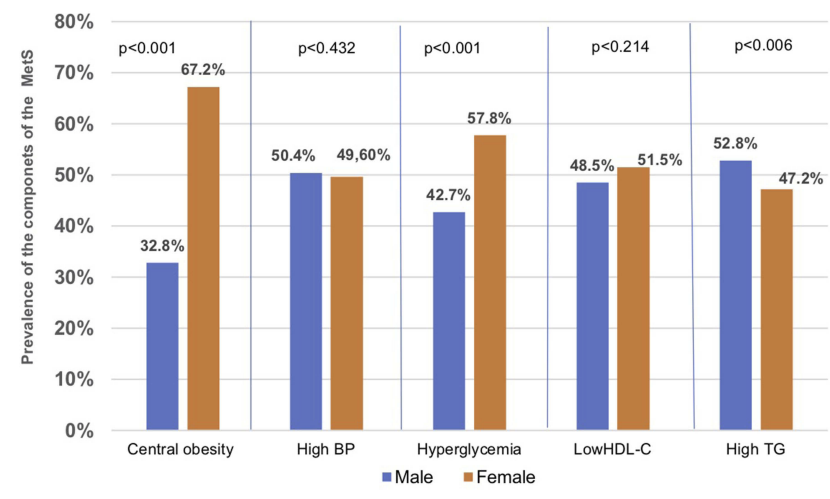

Figure 2 Frequency of each component of metabolic syndrome by gender.

Chi-square tests or the Fisher exact. Variables with a univariate $\mathrm{p}$ - value $<0.25$ were selected for further multivariate analysis. Univariate and multivariate logistic regression analyses were performed to evaluate the association between MetS and other factors. A p-value $<0.05$ was considered as the significance level.

\section{Ethics}

This study was approved by the Palestinian Health Research Council Helsinki Committee and was conducted in accordance with the Declaration of Helsinki. All participants provided written informed consent.

\section{Results}

Among the 2107 participants (1040 males and 1067 females), MetS was found in 864 subjects $(41 \%, 95 \% \mathrm{CI}$ : $39-43)$, with higher rate in females than in males $(50 \%$, 95\% CI:48-52 vs 32\%, 95\% CI: $30-34, \mathrm{p}<0.001)$. Clinical characteristics and metabolic measures of the study population according to MetS are presented in Table 1. Individuals with MetS were more likely to be older, obese, with low physical activity, lower level of education, and had more prevalent cardiovascular risk factors such as diabetes, hypertension and lipid disorders. Also, history of CAD, stroke and LEAD were more prevalent in patients with MetS (12\%, 4.3\%, and $15.5 \%$, respectively). Statins and Aspirin are more commonly used in participants with MetS.

The prevalence of MetS increased with age in both genders, ranging from $13 \%(95 \%$ CI: $11-14)$ in the age category $25-35$ years to $50 \%(95 \%$ CI: $47-52)$ in the age category 55-64 years in males, and from $16 \%$ (95\% CI: $14-17)$ to $79 \%$ (95\% CI: 77-81) in the corresponding age categories in females. The rate decreases after age of 65 years for both genders (Figure 1).

Figure 2 displays the prevalence of each component of the MetS in relation to gender. Central obesity and hyperglycemia were the most common conditions contributing to the MetS mainly in female than in males with significant P-value.

The association of each CVD with the MetS components is reported in Table 2. Low HDL cholesterol level as well as high triglyceride level, hyperglycemia, and elevated blood pressure were the components associated with the highest risk for $\mathrm{CAD}(\mathrm{OR}=2.9,2.7,2.4,2.0$, respectively). While hyperglycemia, high blood pressure and high triglyceride level were the factors associated with the highest risk

Table 2 Association Of CAD, Stroke And LEAD With Each Components Of Metabolic Syndrome

\begin{tabular}{|l|l|l|l|l|l|l|}
\hline \multirow{2}{*}{ Components Of MetS } & \multicolumn{2}{l|}{ CAD } & \multicolumn{2}{l|}{ Stroke } & \multicolumn{2}{l|}{ LEAD } \\
\cline { 2 - 7 } & OR (95\% CI) & P-value & OR (95\% CI) & P-value & OR (95\% CI) & P-value \\
\hline Central obesity & $1.0(0.66-1.45)$ & 0.916 & $1.2(0.61-2.19)$ & 0.643 & $0.8(0.60-1.15)$ & 0.256 \\
High BP & $2.0(1.43-2.90)$ & $<0.001$ & $3.8(2.01-7.31)$ & $<0.001$ & $2.0(1.5 I-2.65)$ & $<0.001$ \\
High triglyceride & $2.7(1.92-3.9 I)$ & $<0.001$ & $3.7(2.00-6.72)$ & $<0.001$ & $0.9(0.68-1.16)$ & 0.386 \\
Low HDL-C & $2.9(1.78-4.55)$ & $<0.001$ & $1.5(0.78-2.72)$ & 0.241 & $0.9(0.66-1.14)$ & 0.305 \\
Hyperglycemia & $2.4(1.67-3.33)$ & $<0.001$ & $4.1(2.32-6.78)$ & $<0.001$ & $1.4(0.98-1.85)$ & 0.06 \\
\hline
\end{tabular}

Note: Each Logistic regression model was adjusted for age and gender.

Abbreviations: BP, Blood pressure; CAD, Coronary artery disease; $\mathrm{Cl}$, confidence interval; HDL-C, high-density lipoprotein cholesterol; LEAD, Lower extremity artery disease; OR, odd-ratio. 
Table 3 Independent Factors Associated With Metabolic Syndrome In Males

\begin{tabular}{|c|c|c|c|c|}
\hline \multirow[t]{2}{*}{ Variables } & \multicolumn{2}{|c|}{ Univariate Analysis } & \multicolumn{2}{|c|}{ Multivariate Analysis } \\
\hline & OR 95\% Cl & P-value & OR $95 \% \mathrm{CI}$ & P-value \\
\hline $\begin{array}{l}\text { Age (years) } \\
\text { Current smoker } \\
\text { Income }\end{array}$ & $\begin{array}{l}1.04(1.03-1.05) \\
1.5(1.14-1.94) \\
1.1(0.85-1.45)\end{array}$ & $\begin{array}{l}<0.001 \\
0.004 \\
0.425\end{array}$ & $1.04(1.03-1.05)$ & $<0.001$ \\
\hline $\begin{array}{l}\text { Marital status } \\
\text { Single } \\
\text { Married } \\
\text { Divorced or widow }\end{array}$ & $\begin{array}{l}\text { Ref. } \\
5.2(2.34-|| .3 \mid) \\
6.8(\mid .86-24.6)\end{array}$ & $\begin{array}{l}<0.001 \\
0.004\end{array}$ & $\begin{array}{l}\text { Ref. } \\
2.3(1.04-5.37)\end{array}$ & 0.039 \\
\hline $\begin{array}{l}\text { Education } \\
\text { Education low } \\
\text { Secondary } \\
\text { High }\end{array}$ & $\begin{array}{l}\text { I.2(0.76-I.78) } \\
\text { I.2(0.93-I.64) } \\
\text { Ref. }\end{array}$ & $\begin{array}{l}0.485 \\
0.137\end{array}$ & & \\
\hline $\begin{array}{l}\text { Physical activity } \\
\text { Low } \\
\text { Moderate } \\
\text { High } \\
\text { Hypertension history } \\
\text { Diabetes history }\end{array}$ & $\begin{array}{l}2.3(1.61-3.39) \\
1.6(1.1-2.3) \\
\text { Ref. } \\
5.1(3.76-6.80) \\
7.1(4.98-10.04)\end{array}$ & $\begin{array}{l}<0.001 \\
0.017 \\
<0.001 \\
<0.001\end{array}$ & $\begin{array}{l}\text { I.7 (1.14-2.47) } \\
\text { Ref. }\end{array}$ & 0.009 \\
\hline $\begin{array}{l}\text { Cardiovascular diseases } \\
\text { CAD } \\
\text { Stroke } \\
\text { LEAD }\end{array}$ & $\begin{array}{l}2.1(1.32-3.02) \\
1.8(0.93-3.62) \\
1.3(0.84-1.92)\end{array}$ & $\begin{array}{l}<0.001 \\
0.079 \\
0.259\end{array}$ & & \\
\hline
\end{tabular}

Note: Multivariate analysis: adjusted for: Age, smoking, marital status, education level, physical activity.

of stroke $(\mathrm{OR}=4.1,3.8,3.7)$ respectively. Elevated blood pressure remains the main component associated with high risk of LEAD (OR=2.0; CI 1.5-2.7; $\mathrm{p}<0.001)$.

The association of MetS with all demographic and cardiovascular variables is separately presented in males and females (Tables 3 and 4). The association with MetS increases with age for both genders. In male gender Low physical activity remains positive $(\mathrm{OR}=1.7$; CI 1.2-2.4; $\mathrm{p}=0.009)$. Also, married males and females were at high risk for MetS $(\mathrm{OR}=2.3$; CI 1.0-5.4; $\mathrm{p}=0.03, \mathrm{OR}=1.9$; CI $1.1-3.3 ; \mathrm{p}=0.04)$, respectively. Furthermore, we failed to detect an association between smoking, education level and physical inactivity with metabolic syndrome.

\section{Discussion}

The current study performed in a large sample of adults in age $\geq 25$ years reveals a high prevalence of MetS in the Palestinian community of the Gaza Strip, up to $41 \%$, based on IDF definition. The prevalence was higher in women $(49.9 \%)$. The prevalence estimated in the current study is superior to that reported in a previous study carried out among a small sample size in different regions of
Palestine. The most recent was a study among 230 adults aged 20-65 years in the Gaza strip, the prevalence of MetS reported was $23 \% .{ }^{10}$ Also, In two different studies in two Palestinian camps in west bank, Rizkallah et al, and Massad et al, reported a prevalence of MetS up to $58 \%$ and $27 \%$ in females. ${ }^{17,18}$ In the present study, central obesity was two times higher in females than in males (67.2\% vs $32.8 \%)$, respectively. Waist circumference as indicator of visceral adiposity has been identified as a stronger predictor of CVD and type 2 diabetes. ${ }^{19}$ The female predominance is not surprising in our study and could be explained by the fact of high and rising frequency of obesity, diabetes and hypertension in our community, mainly in females. ${ }^{20}$ The relationship between the elevated prevalence of MetS in women and android fat distribution and the predominant menopausal components was not analyzed. These factors may contribute to the results. In 2016, the Global Burden of Disease project supported these findings and pointed out that Palestine is one of the countries where the prevalence of obesity and diabetes is very high. ${ }^{21}$ Our results are consistent with those from Middle-East studies, which the burden of MetS was 
Table 4 Independent Factors Associated With Metabolic Syndrome In Females

\begin{tabular}{|c|c|c|c|c|}
\hline \multirow[t]{2}{*}{ Variables } & \multicolumn{2}{|c|}{ Univariate Analysis } & \multicolumn{2}{|c|}{ Multivariate Analysis } \\
\hline & OR $95 \% \mathrm{Cl}$ & P-value & OR $(95 \% \mathrm{Cl})$ & P-value \\
\hline $\begin{array}{l}\text { Age } \\
\text { Current smoker } \\
\text { Income in } \$\end{array}$ & $\begin{array}{l}1.07(1.06-1.09) \\
0.9(0.39-1.87) \\
1.3(1.02-1.7 I)\end{array}$ & $\begin{array}{l}<0.001 \\
0.859 \\
0.004\end{array}$ & $1.07(1.06-1.08)$ & $<0.001$ \\
\hline $\begin{array}{l}\text { Marital status } \\
\text { Single } \\
\text { Married } \\
\text { Divorced or widow }\end{array}$ & $\begin{array}{l}\text { Ref. } \\
2.9(1.8-4.9) \\
5.4(3.1-10.1)\end{array}$ & $\begin{array}{l}<0.001 \\
<0.001\end{array}$ & $\begin{array}{l}\text { Ref. } \\
1.9(1.05-3.34)\end{array}$ & 0.04 \\
\hline $\begin{array}{l}\text { Education level } \\
\text { Education low } \\
\text { Secondary } \\
\text { High }\end{array}$ & $\begin{array}{l}4.4(3.1-6.5) \\
\text { I.8 (I.4-2.4) } \\
\text { Ref. }\end{array}$ & $\begin{array}{l}<0.001 \\
<0.001\end{array}$ & & \\
\hline $\begin{array}{l}\text { Physical activity } \\
\text { Low } \\
\text { Moderate } \\
\text { High } \\
\text { HTN history } \\
\text { Diabetes history }\end{array}$ & $\begin{array}{l}2.1(1.4-2.8) \\
1.2(0.8-1.8) \\
\text { Ref. } \\
9.9(7.05-13.77) \\
19.4(11.3-33.4)\end{array}$ & $\begin{array}{l}<0.001 \\
0.283 \\
<0.001 \\
<0.001\end{array}$ & $\begin{array}{l}\text { I.4 (0.97-I.97) } \\
\text { Ref. }\end{array}$ & 0.075 \\
\hline $\begin{array}{l}\text { Cardiovascular diseases } \\
\text { CAD } \\
\text { Stroke } \\
\text { LEAD }\end{array}$ & $\begin{array}{l}5.2(2.82-9.97) \\
3.1(1.31-7.41) \\
1.4(1.05-1.96)\end{array}$ & $\begin{array}{l}<0.001 \\
0.010 \\
0.048\end{array}$ & & \\
\hline
\end{tabular}

Note: Multivariate analysis: adjusted for: Age, smoking, marital status, education level, physical activity.

estimated to affect a large population, and the prevalence varies from $44 \%$ in Turkey, ${ }^{22} 30 \%$ In Tunisia ${ }^{23}$ to $31.6 \%$ in Saudi Arabia. ${ }^{24}$ In all these reports published in the Middle-East region, the prevalence was also higher in females and the most common components were HDL cholesterol and central obesity. ${ }^{9}$

In our study, the prevalence MetS was found (12.0\%, $4.3 \%$, and $15.5 \%$ ) in subjects with CAD, stroke and LEAD and the association was statistically significant, and the OR increased according to the number of components of MetS. We found that individuals with MetS had a two-fold greater risk of suffering CVDs (CAD, stroke, LEAD) which is similar to the increased risk described for other countries. In a meta-analysis based on NCEP-APIII definition of MetS, the risk estimates were approximately 1.6 for CVD. $^{25-27}$ Gami et al, in a large meta-analysis involving 43 cohorts and 172573 participants found that MetS itself, apart from its components, was associated with an increased risk of cardiovascular events +54 times after adjustment. ${ }^{26}$ In the Botnia study in Finland and Sweden which recruited 4483 subjects aged $35-70$ years, the risk of CAD and stroke tripled in subjects with MetS with an absolute $10 \%$ increase in cardiovascular mortality during 6.9 years of follow-up. ${ }^{28}$

\section{Limitations}

As a cross-sectional design of our study, all associations reported cannot be considered as a causative relationship. Also, possible bias could have been introduced since study was conducted at home and data concerning risk factors were self-reported, another potential concern was that HDL cholesterol, triglycerides, and blood glucose levels were measured only once, which might have led to random error. The strength of the study lies in a large populationbased study representative of the Palestinian community, and we describe for the first time the relationship between MetS and cardiovascular diseases.

\section{Conclusion}

The MetS is a collection of risk factors and a complex condition with high socioeconomic cost, its consequences constitute a heavy burden. Our findings are alarming and should alert 
policy makers to consider primary prevention through a stronger public information to sensitize Palestinians on the hazards of sedentary lifestyle and obesity, because individuals with MetS can be easily screened according to the criteria, it is essential to identify and properly manage each of its components to delay the appearance of its complications.

\section{Acknowledgments}

The authors are grateful to all the families who have welcomed us into their homes and participated in the study. We also thank all nurses who contributed to the study data collection.

\section{Disclosure}

Professor Victor Aboyans reports personal fees from Novartis, Bayer and Sanofi outside the submitted work. The authors report no other conflicts of interest in this work.

\section{References}

1. Wilson PWF, D'Agostino RB, Parise H, Sullivan L, Meigs JB. Metabolic syndrome as a precursor of cardiovascular disease and type 2 diabetes mellitus. Circulation. 2005;112(20):3066-3072. doi:10.1161/CIRCULATIONAHA.105.539528

2. Grundy SM. Metabolic syndrome pandemic. Arterioscler Thromb Vasc Biol. 2008;28(4):629-636. doi:10.1161/ATVBAHA.107.151092

3. Alberti KG, Eckel RH, Grundy SM, et al. Harmonizing the metabolic syndrome: a joint interim statement of the International Diabetes Federation Task Force On Epidemiology And Prevention; National Heart, Lung, and Blood Institute; American Heart Association; World Heart Federation; International Atherosclerosis Society; and International Association for the Study of Obesity. Circulation. 2009;120(16):1640 1645. doi:10.1161/CIRCULATIONAHA.109.192644

4. Alberti KGMM, Zimmet P, Shaw J. The metabolic syndrome-a new worldwide definition. Lancet Lond Engl. 2005;366(9491):1059-1062. doi:10.1016/S0140-6736(05)67402-8

5. Reilly MP, Rader DJ. The metabolic syndrome: more than the sum of its parts? Circulation. 2003;108(13):1546-1551. doi:10.1161/01. CIR.0000088846.10655.E0

6. Andreadis EA, Tsourous GI, Tzavara CK, et al. Metabolic syndrome and incident cardiovascular morbidity and mortality in a Mediterranean hypertensive population. Am J Hypertens. 2007;20 (5):558-564. doi:10.1016/j.amjhyper.2006.12.001

7. Balkau B, Deanfield JE, Després J-P, et al. International Day for the Evaluation of Abdominal Obesity (IDEA): a study of waist circumference, cardiovascular disease, and diabetes mellitus in 168,000 primary care patients in 63 countries. Circulation. 2007;116 (17):1942-1951. doi:10.1161/CIRCULATIONAHA.106.676379

8. Esteghamati A, Zandieh A, Khalilzadeh O, Meysamie A, Ashraf H. Clustering of metabolic syndrome components in a Middle Eastern diabetic and non-diabetic population. Diabetol Metab Syndr. 2010;2:36. doi:10.1186/1758-5996-2-36

9. Sliem HA, Ahmed S, Nemr N, El-Sherif I. Metabolic syndrome in the Middle East. Indian J Endocrinol Metab. 2012;16(1):67-71. doi:10.4103/2230-8210.91193

10. Sirdah MM, Al Laham NA, Abu Ghali AS. Prevalence of metabolic syndrome and associated socioeconomic and demographic factors among Palestinian adults (20-65 years) at the Gaza Strip. Diabetes Metab Syndr. 2011;5(2):93-97. doi:10.1016/j.dsx.2012.02.024
11. Abdul-Rahim HF, Husseini A, Bjertness E, Giacaman R, Gordon NH, Jervell J. The metabolic syndrome in the West Bank population: an urban-rural comparison. Diabetes Care. 2001;24(2):275-279. doi:10.2337/diacare.24.2.275

12. Aboyans V, Criqui MH, Abraham P, et al. Measurement and interpretation of the Ankle-Brachial Index: a scientific statement from the American Heart Association. Circulation. 2012. CIR.0b013e318276fbcb. doi:10.11 61/CIR.0b013e318276fbcb

13. Alberti KG, Zimmet P, Shaw J. Metabolic syndrome-a new worldwide definition. A consensus statement from the International Diabetes Federation. Diabet Med J Br Diabet Assoc. 2006;23 (5):469-480. doi:10.1111/j.1464-5491.2006.01858.x

14. American Diabetes Association. ADA diabetes management guidelines A1C diagnosis | NDEI; 2016. Available from: http://www.ndei. org/ADA-diabetes-management-guidelines-diagnosis-A1C-testing. aspx.html. Accessed January 22, 2018.

15. James PA, Oparil S, Carter BL, et al. 2014 Evidence-based guideline for the management of high blood pressure in adults: report from the panel members appointed to the Eighth Joint National Committee (JNC 8). JAMA. 2014;311(5):507-520. doi:10.1001/jama.2013. 284427

16. WHO hypertension. WHO $\mid$ Q\&As on hypertension. WHO. Published 2015. Available from: http://www.who.int/features/qa/82/en/index. html. Accessed January 9, 2018.

17. Rizkallah N, Marshall T, Kritz-Silverstein D. Parity and risk factors for coronary heart disease in Palestinian women in two refugee camps in the West Bank: a population based cross-sectional survey. Lancet. 2010;382:S28. doi:10.1016/S0140-6736(13)62600-8

18. Massad SG, Khalili M, Karmally W, et al. Metabolic syndrome among refugee women from the West Bank, Palestine: a crosssectional study. Nutrients. 2018;10:8. doi:10.3390/nu10081118

19. Wang Y, Rimm EB, Stampfer MJ, Willett WC, Hu FB. Comparison of abdominal adiposity and overall obesity in predicting risk of type 2 diabetes among men. Am J Clin Nutr. 2005;81(3):555-563. doi:10.1093/ajcn/81.3.555

20. Shahwan JA, Abed Y, Magne J, et al. Epidemiology of cardiovascular disease and associated factors in Gaza-Palestine. PLoS One. 2019.

21. Forouzanfar MH, Bhutta ZA, Burnett R, et al. Global, regional, and national comparative risk assessment of 79 behavioural, environmental and occupational, and metabolic risks or clusters of risks, 1990-2015: a systematic analysis for the Global Burden Of Disease Study 2015. The Lancet. 2016;388(10053):1659-1724. doi:10.1016/ S0140-6736(16)31679-8

22. Gundogan K, Bayram F, Gedik V, et al. Metabolic syndrome prevalence according to ATP III and IDF criteria and related factors in Turkish adults. Arch Med Sci AMS. 2013;9(2):243-253. doi:10.5114/ aoms.2013.34560

23. Belfki H, Ali SB, Aounallah-Skhiri H, et al. Prevalence and determinants of the metabolic syndrome among Tunisian adults: results of the Transition and Health Impact in North Africa (TAHINA) project. Public Health Nutr. 2013;16(4):582-590. doi:10.1017/S1368980 012003291

24. Al-Rubeaan K, Bawazeer N, Al Farsi Y, et al. Prevalence of metabolic syndrome in Saudi Arabia - a cross sectional study. BMC Endocr Disord. 2018;18. doi:10.1186/s12902-018-0244-4

25. Ford ES. Risks for all-cause mortality, cardiovascular disease, and diabetes associated with the metabolic syndrome: a summary of the evidence. Diabetes Care. 2005;28(7):1769-1778. doi:10.2337/diacare. 28.7.1769

26. Gami AS, Witt BJ, Howard DE, et al. Metabolic syndrome and risk of incident cardiovascular events and death: a systematic review and meta-analysis of longitudinal studies. $J$ Am Coll Cardiol. 2007;49 (4):403-414. doi:10.1016/j.jacc.2006.09.032 
27. Galassi A, Reynolds K, He J. Metabolic syndrome and risk of cardiovascular disease: a meta-analysis. Am J Med. 2006;119 (10):812-819. doi:10.1016/j.amjmed.2006.02.031
28. Isomaa $\mathrm{B}$, Almgren $\mathrm{P}$, Tuomi $\mathrm{T}$, et al. Cardiovascular morbidity and mortality associated with the metabolic syndrome. Diabetes Care. 2001;24(4):683-689. doi:10.2337/diacare.24.4.683

\section{Publish your work in this journal}

Diabetes, Metabolic Syndrome and Obesity: Targets and Therapy is an international, peer-reviewed open-access journal committed to the rapid publication of the latest laboratory and clinical findings in the fields of diabetes, metabolic syndrome and obesity research. Original research, review, case reports, hypothesis formation, expert opinion and commentaries are all considered for publication. The manuscript management system is completely online and includes a very quick and fair peer-review system, which is all easy to use. Visit http://www.dovepress.com/testimonials.php to read real quotes from published authors. 